\title{
A New Way of Getting the Charge with Diamond Fraction
}

T. S. Skoblo ${ }^{1}$, O. V. Nanka ${ }^{1}$, Yu. M. Kuskov ${ }^{2}$, O. V. Saychuk ${ }^{1}$, V. M. Romanchenko ${ }^{1}$, S. P. Romanyuk ${ }^{1}$, I. M. Ryibalko ${ }^{1}$, O. V. Markov ${ }^{3}$, Yu. V. Samsonov ${ }^{3}$, and T. V. Maltsev ${ }^{4}$

\author{
${ }^{1}$ Kharkiv Petro Vasylenko National Technical University of Agriculture, \\ 44, Alchevskikh Str., \\ UA-61002 Kharkiv, Ukraine \\ ${ }^{2}$ E. O. Paton Institute of Electric Welding, N.A.S. of Ukraine, \\ 11, Kazimir Malevich Str., \\ UA-03150 Kyiv, Ukraine \\ ${ }^{3}$ National Academy of the National Guard of Ukraine, \\ 3, Defenders of Ukraine Square, \\ UA-61001 Kharkiv, Ukraine \\ ${ }^{4}$ State Enterprise 'Malyshev Plant', \\ 126, Plekhanivska Str., \\ UA-61037 Kharkiv, Ukraine
}

A method for producing the secondary charge with nano- and dispersed diamond fractions by the detonation method for the modifying and hardening of metal, which is effective in restorative hard facing of parts by hardening coatings, welding of defects, increasing the operational resistance of mating parts by adding them to grease is developed. The proposed method is based on the getting of the charge from the disposal of ammunition special set with reusable detonation, which ensures stable obtaining of diamond fraction and modifying additives. The qualitative and quantitative analyses of the charge components, which are divided into magnetic and non-magnetic ones, are done. The optimal proportion of the modifying additives for the use of them, when entering into the liquid bath during hard facing, is determined.

Розроблено спосіб одержання вторинного заряду з нано- та дисперсною діямантовими фракціями детонаційною методою для модифікування та зміцнення металу, що є ефективним при відновлювальному натопленні деталів зміцнювальними покриттями з твердих стопів, заварюванні дефектів, підвищенні експлуатаційної стійкости спряжених деталів додаванням їх у пластичне мастило. Таку методу одержання шихти засновано на утилізації відповідного складу боєприпасів із багаторазовою 
детонацією, що забезпечує одержання стабільної фракції діямантів і модифікувальних домішок. Виконано якісну та кількісну аналізи вмісту компонентів шихти, яких поділено на магнетну та немагнетну складові. Встановлено оптимальну частку використання їх для модифікування рідкого розчину при натопленні.

Key words: nano- and dispersed diamonds, detonation, ammunition, disposal, composition of the charge.

Ключові слова: нано- та дисперсні діяманти, детонація, боєприпаси, утилізація, вміст шихти.

(Received 2 June, 2020)

\section{INTRODUCTION}

Deep research for obtaining diamond fractions are carried out in the field of physics and chemistry using various methods for their preparation. At the same time, their properties are evaluated and features in the structure formation and the possibility of use for modification are predicted. To a lesser extent, studies are being carried out to use such additives in liquid metal in the production of parts and their restoration and operation. This is due to the fact that each area of use requires the provision of specific application properties stipulated by normative and technical documentation.

Most often, alloying and modifying additives are used to increase the durability of parts. Additional alloying significantly increases the cost of manufacturing products. Therefore, more often, it is used the introduction of modifying additives, which, when restored, provide the required physical and mechanical properties of the material: it is grinding the grain size during crystallization with contribution to the formation of more uniform structure. As such modifying additives, oxides, nitrides and, more recently, diamond fractions are used. To increase the effect from using the diamond modifier, it is specially treated with the application of coatings consisting of various components.

These are such as Ni, Cr, Ti, Co-Ni, Ni-W, Ti-Cr, Ti-W [1, 2]. To modify the diamond fraction with additional components, they are applying to it by multistage processing, including special roll forming and sintering at various temperatures $\left(750\right.$ and $\left.900^{\circ} \mathrm{C}\right)$. Such technology for producing a powder composition is quite expensive.

This work proposes a method for producing powder composition obtained in the form of secondary raw materials from the disposal of a specific set of ammunition that has expired.

The aim of the work is developing the method for producing the 
stable nano- and dispersed diamond fractions, and saturating them in the form of coatings with modifying, microalloying components based on secondary raw materials after the disposal of ammunition.

To achieve this aim, it was necessary:

to select the type of disposable ammunition;

to develop the method for their disposal;

to estimate the composition of the resulting mixture and its modifying effect due to the obtaining the diamond fraction and constituent components.

\section{OBJECT AND METHODS OF RESEARCH AND OBTAINING SECONDARY RAW MATERIALS}

Based on the requirements for hardening restoring coatings, we analyzed materials of various types of cartridges that can be disposed in a small container.

The $12.5 \mathrm{~mm}$ live and $15 \mathrm{~mm}$ signal cartridges are most effective; the proportions of them are $99.0 \%$ and $10 \%$, respectively. The number of signal cartridges should not exceed this number, since they include $\mathrm{Mg}$, which will significantly increase the pyroeffect and provide local detonation up to $3000^{\circ} \mathrm{C}$. Such ammunition has complex structure, for which materials of different composition are used. The composition of the cartridges also includes gunpowder, and this does not require additional use of explosives during their disposal.

When choosing the starting material during detonation, it was also taken into account that the $\mathrm{Cu}$ and $\mathrm{Zn}$ components stabilize

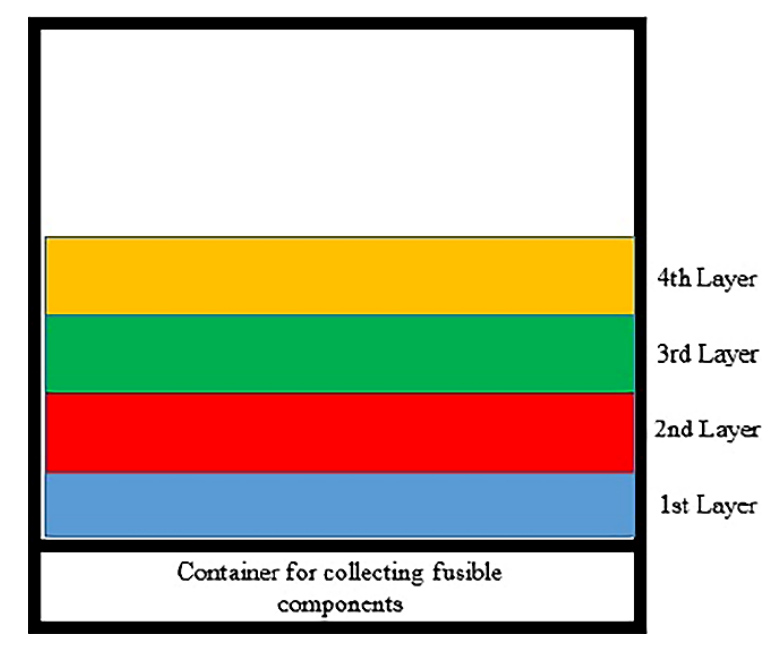

Fig. 1. Scheme of ammunition in the furnace for detonation. 
such process.

For detonation, we used a container (Fig. 1) of $1 \mathrm{~m}^{3}$ volume with holes on its surface, sidewalls, and bottom to remove gases and fusible components. Such holes were formed with diameter of $6 \mathrm{~mm}$ and placed at distance of $50 \mathrm{~mm}$ from each other. The container for detonation was installed in the field at distance of $1.5 \mathrm{~km}$ from the buildings. Before lying in the container, the cartridges were packed in bundles of 10 pieces and laid in four layers, and then, set on fire-the lower (first bundle). The detonation time of each layer varied: for $1^{\text {st }}$ one, it was of 1-2 s; for $2^{\text {nd }}$ one, it was of $2-3 \mathrm{~s}$; for $3^{\text {rd }}$ one, it was of $3-5 \mathrm{~s}$; for $4^{\text {th }}$ one, it was of 5-10 s (Fig. 2). Signal cartridges were distributed evenly in bundles with the lighting ones of each layer. This provided an average temperature of the detonation of $1500-1800^{\circ} \mathrm{C}$.

A distinctive feature of this detonation method is obtaining the mixture with stable diamond phase and the ability to simultaneous obtaining the modifying components.

To study the qualitative and quantitative compositions of the charge, chemical and spectral analyses, electron microscopy methods, and local spectral analysis were used.

To use such mixture to achieve specific properties, it can easily be divided into fractions (small non-magnetic, magnetic, and largemixed ones). Depending on the type of fraction, it can be effectively used for various purposes in metallurgy, engineering, the oil and gas industry as modifying additive in metal [3] and grease to stabi-

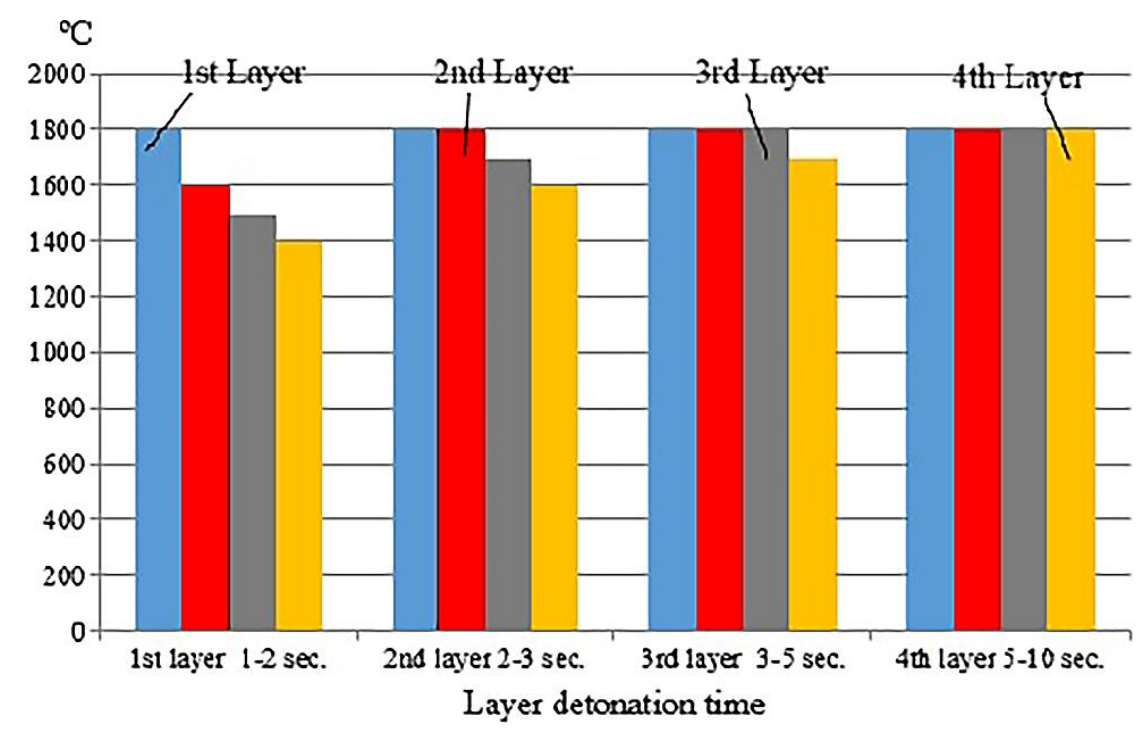

Fig. 2. Changing the time and temperature of the explosion of each layer. 
lize the operation of equipment [4].

This paper presents the results of analysis of the secondary charge composition of small fractions (magnetic and non-magnetic ones) with nano- and dispersed diamonds.

\section{RESULTS OF THE RESEARCH}

When disposing of ammunition, conglomerates of different sizes are formed, which are crushed and analyzed by various methods. At the first stage, the properties were evaluated by chemical analysis. In this case, the average contents of the main components included in the metal of the cartridges, namely, $\mathrm{Fe}, \mathrm{Cu}$, and $\mathrm{C}$, were determined. It was established that their share in such charge are: 3.47$3.43 \%$ of $\mathrm{C} ; 3.14 \%$ of $\mathrm{Cu}$, and up to $100 \%$ of $\mathrm{S}, \mathrm{Ca}, \mathrm{Mg}, \mathrm{K}, \mathrm{Na}, \mathrm{Fe}$, $\mathrm{O}_{2}$.

To identify all possible components included in the fine fraction of the mixture, we analyzed their contents by the method of spectral analysis of conglomerate-fragmented grains. Table 1 and Figure 3 show statistical analysis of the components' content in the grains of the magnetic charge and, selectively, in the conglomerate, respectively.

TABLE 1. The chemical composition of the magnetic component of the charge.

\begin{tabular}{|c|c|c|c|c|c|c|c|c|c|}
\hline \multirow[t]{2}{*}{ Element } & \multicolumn{2}{|c|}{$\begin{array}{c}\text { Conglomerate } \\
1\end{array}$} & \multicolumn{2}{|c|}{$\begin{array}{c}\text { Conglomerate } \\
2 \\
\end{array}$} & \multicolumn{2}{|c|}{$\begin{array}{c}\text { Conglomerate } \\
3 \\
\end{array}$} & \multicolumn{2}{|c|}{\begin{tabular}{|c} 
Conglomerate \\
4 \\
\end{tabular}} & \multirow{2}{*}{$\begin{array}{l}\text { Average } \\
\text { value }\end{array}$} \\
\hline & $\%$ & Error & $\%$ & Error & $\%$ & Error & $\%$ & Error & \\
\hline $\mathrm{Ti}$ & 11.83 & 0.36 & 9.14 & 0,28 & 10.83 & 0.28 & 10.67 & 0.34 & 10.61 \\
\hline $\mathrm{Cr}$ & 0.69 & 0.06 & 0.48 & 0.04 & 0.57 & 0.04 & 0.53 & .05 & 0.57 \\
\hline Mn & 0.43 & 0.04 & 0.36 & 0.03 & 0.38 & 0.03 & 0.36 & .03 & .38 \\
\hline $\mathrm{Fe}$ & 6.81 & & 13.7 & 0.13 & 5.0 & 0.07 & 8.31 & .11 & 8.46 \\
\hline Co & 0.8 & 0.04 & 1.21 & 0.04 & 0.58 & 0.02 & 0.74 & 0.03 & 0.84 \\
\hline $\mathrm{Ni}$ & 0.18 & 0,02 & 0,08 & 01 & 0,17 & 0.01 & 0,13 &, 01 & 0,14 \\
\hline $\mathrm{Cu}$ & 25.99 & 0.18 & 20.64 & 14 & 37.79 & 0.19 & 17.23 & .13 & 25.41 \\
\hline $\mathrm{Zn}$ & 11.83 & & & 06 & 17.16 & 0.1 & 5.9 & .06 & 10.45 \\
\hline $\mathrm{Y}$ & 0.8 & & 1.0 & 02 & 0.47 & 0.01 & 1.24 & .02 & 0.9 \\
\hline Mo & 0.14 & 0.001 & 0.07 & 0.01 & 0.08 & 0.01 & 0.07 & .01 & 0.09 \\
\hline $\mathrm{Ag}$ & 0.06 & & 0.2 & 01 & 0.27 & 0.01 & 0.41 & 1 & 0.75 \\
\hline $\mathrm{Cd}$ & 2.13 & & 0.8 & 02 & 1.02 & 0.02 & 0.9 & 0.02 & 1.23 \\
\hline $\mathrm{Sn}$ & 3.99 & 0.0 & 1.64 & 0.03 & 2.05 & 0.04 & 1.75 & 0.04 & 2.36 \\
\hline $\mathrm{Sb}$ & 1.72 & 0.0 & 0. & 0.02 & 0.92 & 0.02 & 0.77 & 0.02 & 1.03 \\
\hline $\mathrm{Au}$ & 0.66 & 0.03 & 0.7 & .02 & 0.71 & 0.03 & 0.87 & 0.03 & 0.75 \\
\hline $\mathrm{Pb}$ & 31.92 & 0.24 & 42.1 & 0.22 & 22.0 & 0.19 & 50.13 & 0.26 & 36.54 \\
\hline
\end{tabular}



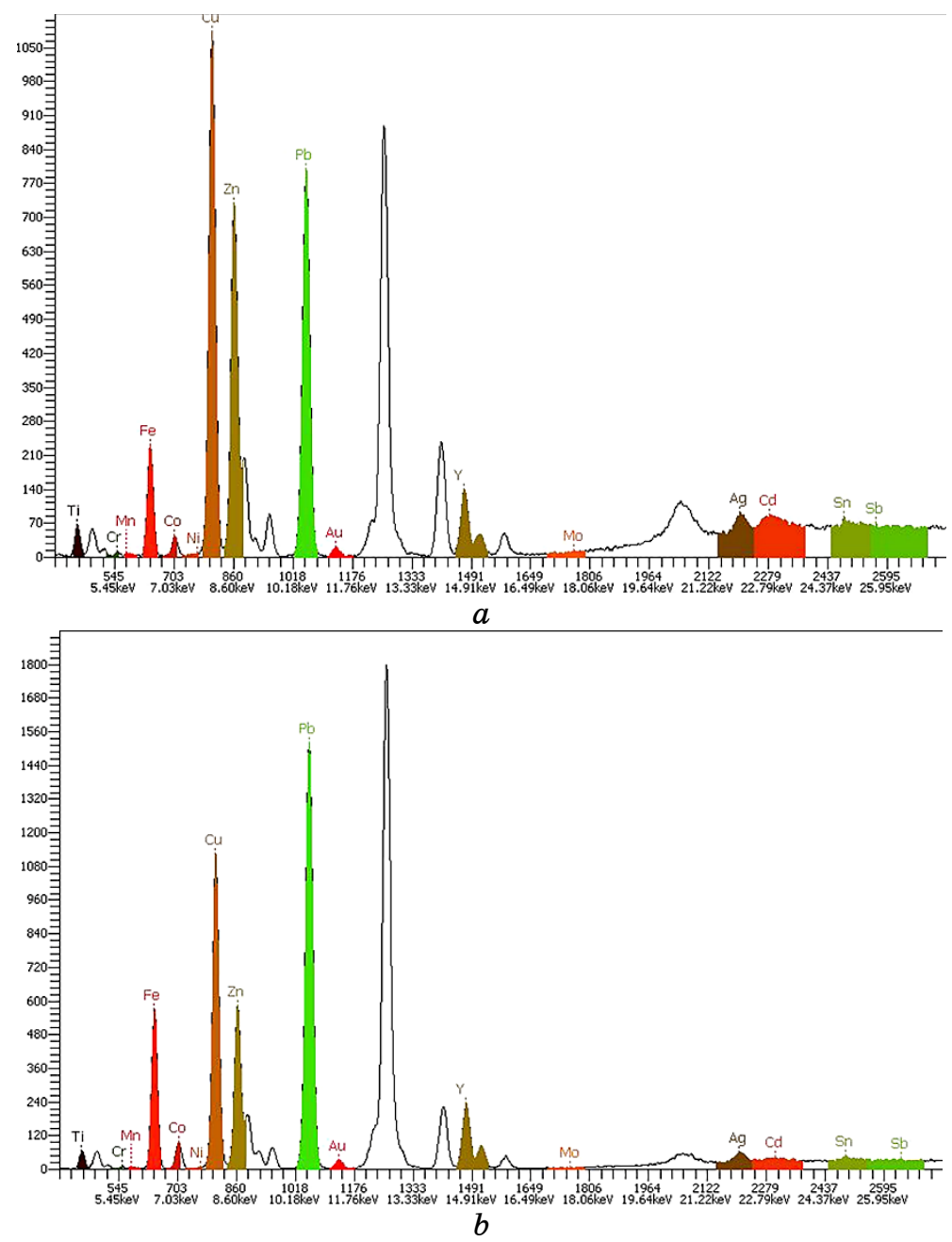

Fig. 3. The distribution of components in two grains of magneticcomponent conglomerate of the charge.

The measurement error is of $0.004-0.36 \%$, where the minimum corresponds to Mo, and the maximum corresponds to Ti.

The above analysis shows that the maximum dispersion of readings in the fine magnetic fraction is characteristic for components with higher their content in the charge: $\mathrm{Fe}, \mathrm{Ti}, \mathrm{Cu}, \mathrm{Zn}$, and $\mathrm{Pb}$.

At the same time, the analysis did not reveal such components as, for example, $\mathrm{C}, \mathrm{Mg}, \mathrm{Si}$, and other modifying additives.

It can be assumed that such components are not distributed evenly in the conglomerate of grains or cannot be detected by this method. This is especially true for the diamond phase. Therefore, we 


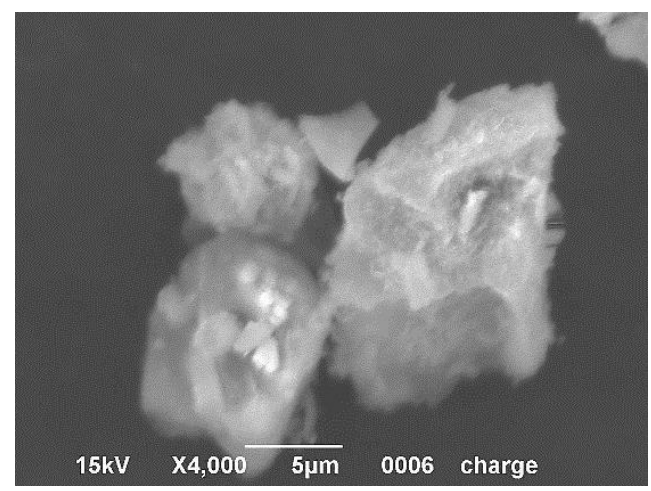

Fig. 4. The diamond fraction in the non-magnetic component of the charge.

conducted detailed local studies of grains to assess their structure with the identification of the diamond fraction.

Statistical electron-microscopy analysis and local x-ray diffraction revealed multilayer coatings on diamond fractions, which are easily deformed during detonation, since they are located both inside the conglomerate grains of different sizes and along their boundaries in the form of film coating $(\times 10000$, Fig. 4$)$.

At the same time, there are conglomerates consisting of metal oxides in the non-magnetic component of the charge, and they are less deformed during detonation. In the first case, during cyclic detonation, the diamond fraction is crushed to nano- and dispersed inclusions, and in the second case, their size is much larger and is measured in microns. This is due to the fact that such inclusions are sintered in weakly deformable shell of metal oxides. At the same time, the diamond fraction in these two variants of formation of the conglomerate grains is stable due to this method of detonation, and this is confirmed by the fact that, during five years of storage, it does not decompose with the formation of graphite. The diamond phase with a less plastic coating is better detected when using such charge in the structure, applied hardening coating.

Figures 4 and 5 show the diamond fraction detected in the nonmagnetic and magnetic fractions of the charge, respectively.

The non-magnetic component of the charge was estimated by the method of spectral analysis (Table 2), which showed that its main constituents are as follow (in \%): 6.42 of Fe (possibly, $\gamma$-Fe); 13.30 of $\mathrm{Cu} ; 5.69$ of $\mathrm{Al} ; 8.23$ of $\mathrm{Ti} ; 13.37$ of $\mathrm{Mg} ; 1.63$ of $\mathrm{V} ; 5.88$ of $\mathrm{Zn}$; 16.98 of $\mathrm{Sn}$.

When comparing the various types of the charge, it is clear that they differ significantly. Thus, significant content of impurities was revealed in the magnetic component, which can reduce the modifying effect during hard facing and hardening of restorative coat- 

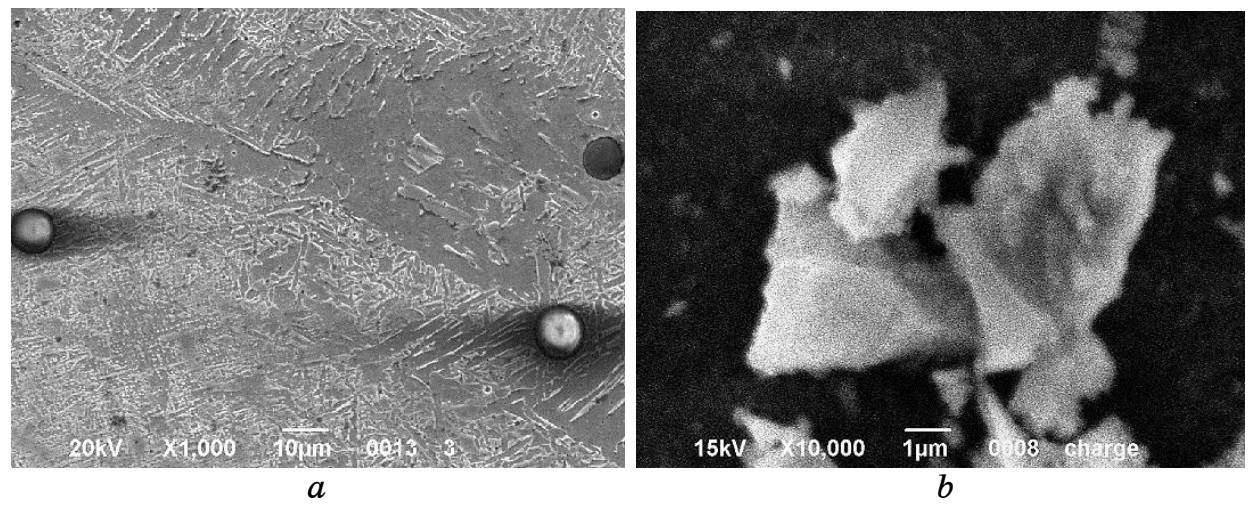

Fig. 5. The diamond fraction detected in the magnetic charge during hard facing.

ings, and its use requires further investigation in production conditions. In such fraction of the charge, the Fe content is also increased, and of the modifying additives, only yttrium is present, the proportion of which in individual conglomerates varies in the range of $0.471-1.244 \%$.

The most effective component for hardening of restorative coatings is the non-magnetic component of the charge with nano- and dispersed diamonds. It contains more modifying additives: $\mathrm{Al}, \mathrm{Mg}$, Y.

The content of components in the non-magnetic fraction of the charge, estimated by the spectral method, is given in Table 2.

Such charge includes 24 constituents that is $33 \%$ more than the magnetic component, in which there are no $\mathrm{Al}, \mathrm{Si}, \mathrm{Zn}, \mathrm{V}, \mathrm{Hf}, \mathrm{Ta}$, $\mathrm{W}, \mathrm{Bi}$, and Ag. Moreover, from the entire statistical sample, such components are mostly present in single grains, although in some of them, the average concentration reaches $13.37 \%$ of $\mathrm{Mg}, 5.69 \%$ of $\mathrm{Al}, 1.63 \%$ of $\mathrm{V}$, and $0.86 \%$ of $\mathrm{W}$. The average proportion of the remaining components detected in single grains of conglomerate does not exceed $0.01-0.58 \%$.

Some of components, which are included in the magnetic component of the charge, differ significantly in concentration. Thus, the fraction of $\mathrm{Ti}, \mathrm{Sb}, \mathrm{Fe}$, and $\mathrm{Pb}$ in it is $25 \%$ and $39 \%$ higher, respectively, and $\mathrm{Cu}, \mathrm{Zn}$, and $\mathrm{Co}$ are 2 times higher than non-magnetic component. The concentration of $\mathrm{Y}, \mathrm{Ca}, \mathrm{Mo}$, and $\mathrm{Cd}$ in the compared types of charge is rather close, and magnesium is absent.

When using the non-magnetic component of the charge as the modifying additive, introduction of it is also most effective in the amount of $5-7 \%$ of the electrode or wire fraction. When recalculating, the average input fraction of the modifying additive in the liq- 
TABLE 2. The chemical composition of the non-magnetic component of the charge.

\begin{tabular}{|c|c|c|c|c|c|c|}
\hline \multirow{2}{*}{ Element, \% } & \multicolumn{5}{|c|}{ No of grain } & \multirow{2}{*}{ Average value } \\
\hline & 1 & 2 & 3 & 4 & 5 & \\
\hline $\mathrm{Mg}$ & - & 66.83 & - & - & - & 13.37 \\
\hline $\mathrm{Al}$ & - & 28.46 & - & - & - & 5.69 \\
\hline $\mathrm{Si}$ & - & 1.95 & - & - & - & 0.39 \\
\hline $\mathrm{Ti}$ & 20.19 & - & - & 11.01 & 9.96 & 8.23 \\
\hline $\mathrm{V}$ & 8.16 & - & - & - & - & 1.63 \\
\hline $\mathrm{Cr}$ & 1.17 & - & - & 0.66 & 0.54 & 0.47 \\
\hline $\mathrm{Mn}$ & 0.86 & 0.04 & - & 0.46 & 0.44 & 0.36 \\
\hline $\mathrm{Fe}$ & 6.23 & 0.46 & 4.91 & 9.61 & 10.88 & 6.42 \\
\hline $\mathrm{Ni}$ & 0.01 & - & - & 0.21 & 0.18 & 0.08 \\
\hline $\mathrm{Cu}$ & 7.81 & 1.45 & 9.15 & 25.01 & 23.09 & 13.30 \\
\hline $\mathrm{Zn}$ & - & 0.82 & 4.63 & 11.36 & 12.61 & 5.88 \\
\hline $\mathrm{Y}$ & 2.58 & - & - & 0.72 & 0.77 & 0.82 \\
\hline $\mathrm{Zr}$ & 0.24 & - & - & - & - & 0.05 \\
\hline Mo & 0.44 & - & - & 0.18 & 0.13 & 0.15 \\
\hline $\mathrm{Sn}$ & 5.48 & - & 71.19 & 4.52 & 3.7 & 16.98 \\
\hline $\mathrm{Hf}$ & 2.9 & - & - & - & - & 0.58 \\
\hline $\mathrm{Ta}$ & 0.41 & - & - & - & - & 0.08 \\
\hline $\mathrm{W}$ & 4.24 & - & - & - & - & 0.85 \\
\hline $\mathrm{Pb}$ & 39.24 & - & 8.13 & 30.39 & 34.67 & 22.48 \\
\hline $\mathrm{Bi}$ & 0.06 & - & - & - & - & 0.01 \\
\hline $\mathrm{Ag}$ & - & - & 0.4 & 0.08 & - & 0.10 \\
\hline $\mathrm{Sb}$ & - & - & 1.6 & 2.09 & - & 0.74 \\
\hline Co & - & - & - & 1.12 & 1.09 & 0.44 \\
\hline $\mathrm{Cd}$ & - & - & - & 2.58 & 1.94 & 0.90 \\
\hline
\end{tabular}

uid bath will be as follow (in \%): 0.8 of $\mathrm{Mg}$; 0.34 of $\mathrm{Al} ; 0.02$ of $\mathrm{Si}$; 0.49 of $\mathrm{Ti} ; 0.03$ of $\mathrm{Fe}$; 0.005 of $\mathrm{Ni} ; 0.003$ of $\mathrm{Zr} ; 0.1$ of $\mathrm{V} ; 0.03$ of $\mathrm{Cr} ; 0.02$ of $\mathrm{Mn}$; 0.8 of $\mathrm{Cu} ; 0.35$ of $\mathrm{Zn} ; 0.05$ of $\mathrm{Y} ; 0.01$ of $\mathrm{Mo} ; 0.22$ of $\mathrm{Hf} ; 0.005$ of $\mathrm{Ta} ; 0.05$ of $\mathrm{W} ; 1.35$ of $\mathrm{Pb} ; 0.21$ of $\mathrm{C}$ (nano- and dispersed diamonds).

Based on the information obtained about the components and their share in the mixture, when using non-magnetic component of the fraction as a modifier, it follows that the main modifying additives are $\mathrm{Mg}, \mathrm{Al}, \mathrm{Ti}$, and $\mathrm{Cu}$. The average amount of diamond fraction estimated by the carbon fraction by chemical analysis in such mixture is of $3.45 \%$ of $\mathrm{C}$, and when introduced with the mixture for modification, it will not exceed $0.21 \%$. When applying restorative coatings, components with a low melting point will float to the 
surface and will be removed by machining.

Studies on the use of such charge, taking into account its composition and the proportion of input components, have confirmed the feasibility for parts and constructions [5-7], which are used in various conditions of production and operation: hard facing of restorative coatings, welding of defects, and introducing into grease to stabilize the operation of fit.

\section{CONCLUSIONS}

A new technological process is proposed for producing nano- and dispersed diamonds in the detonation secondary charge from the disposal of ammunition specific set that has served its shelf life. For detonation, live $12.5 \mathrm{~mm}$ cartridges $(99.0 \%)$ and $15 \mathrm{~mm}$ signal cartridges $(1.0 \%)$ were used.

A type of container for disposal and a method for the detonation of such ammunition as well as a method for their placement are proposed. This ensured their cyclic deformation as well as the formation of stable diamond phase and the removal of significant proportion of volatile and low-melting components.

The resulting detonation charge is easily divided into fractions: small (magnetic and non-magnetic) and large mixed ones. The performed studies showed that different fractions of the charge differ in the chemical composition and size of the diamond component. Nanodiamonds are formed largely in the non-magnetic component of the charge, and they are coated with plastic compounds. In the magnetic component, diamonds cover metal oxides, which prevent the destruction of this phase, and it is sintered during cyclic detonation.

Qualitative and quantitative comparative spectral analyses of the grains' conglomerate constituents of the magnetic and non-magnetic components of the charge were performed. It is shown that the first ones contain 16 constituents, and the second ones contain 24 constituents. They differ in the share of modifying components, which are found in individual grains.

Studies have established that the maximum proportion of the modifying additive corresponds to the non-magnetic fraction of the charge.

Based on the composition of the charge, it is recommended to use it for the modification of liquid metal during restorative hard facing in the amount of $5-7 \%$ of the electrode or wire fraction.

Depending on the type of charge (magnetic or non-magnetic one), its use is effective for various conditions of hardening and increasing the operational stability of parts. 


\section{REFERENCES}

1. T. M. Duda, T. D. Ilnitskaya, L. A. Romanko, O. O. Pasechny, V. V. Smokvina, A. A. Devitsky, V. N. Weaver, V. I. Lavrinenko, I. N. Zaitsev, T. A. Kosenchuk, S. V. Gaidai, and A. N. Shehanin, Journal of Superhard Materials, 17: 226 (2015) (in Russian).

2. T. M. Duda, Yu. I. Nikitin, and V. G. Poltoratsky, Journal of Superhard Materials, 5: 88 (2000) (in Russian).

3. T. S. Skoblo, O. V. Nanka, O. I. Sidashenko, Yu. M. Kuskov, O. V. Saychuk, S. P. Romaniuk, O. V. Markov, and Yu. V. Samsonov, Sposib Oderzhannya Detonatsiynoyi Shykhty z Almaznoyu Fraktsieyu [Method of Obtaining Detonation Charge with a Diamond Fraction] (Patent No. 138685 of Ukraine, B22D 19/00, B22D 19/08 (Korysna Model', No. 23) (2019)) (in Ukrainian).

4. T. S. Skoblo, A. I. Sidashenko, and I. N. Rybalko, Napryazheniya i Degradatsiya Struktury, Formiruemyye v Buril'nykh Trubakh pri Ehkspluatatsii [Stresses and Structural Degradation Formed in Drill Pipes During Operation] (Kharkiv: PromArt: 2018) (in Russian).

5. T. S. Skoblo, A. I. Sidashenko, and O. V. Saychuk, Korpusni Detali $z$ Chavuniv ta Yikh Yakisni Pokaznyky [Cast Iron Body Parts and Their Quality Indicators] (Kharkiv: Disa Plus: 2019) (in Ukrainian).

6. T. S. Skoblo, O. I. Sidashenko, S. P. Romaniuk, O. O. Honcharenko, L. V. Omelchenko, and V. A. Bantkovskiy, Physico-Chemical Mechanics of Materials, 55, No. 6: 96 (2019) (in Ukrainian).

7. T. S. Skoblo, O. I. Sidashenko, S. P. Romaniuk, L. V. Omelchenko, O. O. Honcharenko, and O. D. Martynenko, Sposib Pidvyshchennya Ehkspluatatsiynoyi Stiykosti Spryazhen' pry Vidnovlenni Detaley [A Method to Increase the Operational Stability of the Mates During the Restoration of Parts] (Patent No. 137676 of Ukraine, B23P 6/04, B23K 9/00, B23K 35/22, C23C 8/00 (Korysna Model', No. 21) (2019)) (in Ukrainian). 